Ben Richard Hughes, Fatemeh Rezazadeh, Hassam Nasarullah Chaudhry, Economic viability of incorporating multi-effect distillation with district cooling systems in the United Arab Emirates, Sustainable Cities and Society, Volume 7, July 2013, Pages 37-43, ISSN 2210-6707, http://dx.doi.org/10.1016/j.scs.2012.10.002.

\title{
Economic Viability of Incorporating Multi-Effect Distillation with District Cooling Systems in the United Arab Emirates
}

\section{Dr. Ben Richard Hughes}

School of Civil Engineering, Faculty of Engineering, University of Leeds, United Kingdom.

B.R.Hughes@leeds.ac.uk, Tel: +44 (0)113 3431638 Fax: +44 (0)113 3431640.

\section{Ms. Fatemeh Rezazadeh}

MSc Energy Programme, School of Engineering and Physical Sciences, Heriot-Watt University, Dubai, United Arab Emirates

\section{Mr. Hassam Nasarullah Chaudhry}

School of Civil Engineering, Faculty of Engineering, University of Leeds, United Kingdom.

\begin{abstract}
The United Arab Emirates (U.A.E.) has one of the most advanced and developed desalination systems in the world, mainly located along the shore. The aim of this study is to analyze the economic feasibility of incorporating the two most prominent types of desalination systems within the existing district cooling plants in the U.A.E by utilizing waste heat recovery. Mathematical models are established to compare Reverse Osmosis (R.O) with Multi-Effect Distillation (M.E.D) technology coupled with district cooling in terms of capital and operational costs. Calculated power consumptions were $5.65 \mathrm{MW}$ and $6.65 \mathrm{MW}$ for reverse osmosis and multi-effect distillation respectively. Total capital expenditure during the system life-cycle of 15 years was estimated at US\$3.3million for reverse osmosis and US\$3.9million for multi-effect distillation technique, both in combination with district cooling. The results indicate that the multi-effect distillation technique integrated with district cooling consumes approximately $25 \%$ less operational costs than the reverse osmosis integrated district cooling over their life-cycle. Furthermore with energy prices set to rise over the next decade the reduction of power consumption through heat recovery demonstrates the long-term viability of introducing the incorporation of multi-effect distillation technique with district cooling systems in the region.
\end{abstract}

\section{Keywords:}

Desalination, district cooling, multi-effect distillation, reverse-osmosis, operational cost 


\section{INTRODUCTION}

The United Arab Emirates (U.A.E) has seen rapid expansion over the last decade with has seen the influx of foreign nationals to expand the population to record levels. The U.A.E is a harsh natural environment requiring extensive district cooling and desalinated water supplies for the population. The increase in production of these essential elements coupled to the rapid construction and transportation development has given the U.A.E one of the largest carbon footprint per capita.

This study proposes to combine the two technologies by using waste heat recovery from the district cooling process to reduce power consumption required in the desalination process. This technology is currently in use in Europe, therefore the focus is on the feasibility of implementing it into the region and the long term potential of such a solution.

The Persian Gulf is an extension of the Indian Ocean located between Iran (formerly called Persia) and the Arabian Peninsula. The Persian Gulf is a shallow semi-enclosed sea connected to the Gulf of Oman via the narrow Strait of Hormuz, with a mean depth of $35 \mathrm{~m}$ [1]. It covers an area of about $240,000 \mathrm{~km}^{2}$, and is $1000 \mathrm{~km}$ in length with widths ranging from 185 to $340 \mathrm{~km}$. Seawater in the Gulf is naturally characterized by higher salt content due to high evaporation with an annual mean rate of $2.0 \mathrm{~m} /$ year where surface salinity values exceeding 40ppt were recorded, especially in the shallow waters around the island of Bahrain and the coasts of Qatar and the U.A.E. [2, 3]. Dense, saline water formed by evaporation tends to sink, and eventually flows around the tip of the Musandam peninsula through the deepest part of the Strait of Hormuz into the Gulf of Oman. Along the shallower coast of Iran, there is a replacement surface inflow with a salinity of $37.5 \mathrm{ppt}$ [4].

Seawater temperatures vary between $15^{\circ} \mathrm{C}$ in the winter and $35^{\circ} \mathrm{C}$ in the summer in the GCC countries (United Nations, 2001). The circulation exchanges water between the Persian Gulf and the Gulf of Oman via the Strait of Hormuz [1]. The circulation in and out of the Strait of Hormuz is very limited. It is estimated to be in the range of two to five years [5]. The evaporation is very high for most of the year, estimated at a rate of 140 to $500 \mathrm{~cm}$ annually. The temperature of the seawater is in the range of $12^{\circ}$ to $35^{\circ} \mathrm{C}$ in the winter and summer, respectively, with an average of $23.1^{\circ} \mathrm{C}$ [6]. Furthermore, the Persian Gulf is characterized by marked seasonal extremes in inshore $\left(10-39^{\circ} \mathrm{C}\right)$ and offshore $\left(18-33^{\circ} \mathrm{C}\right)$ water temperatures [7].

Weather has an important effect on the seawater of the Gulf. Predominant wind flow across the water surface in conjunction with tidal patterns creates wave action. Oxygen, a prime requisite of many marine life forms, becomes infused in the sea due to the breakup of the surface water skin through wave action (surf). Continuous sunlight, particularly in the summer months, warms the water surface, causing evaporation levels to increase. The combination of both wind and solar energy can lead to very high evaporation levels, especially in shallower and lagoon areas. It has been said that the total annual input of fresh water from the Tigris and Euphrates is less than that 
which evaporates from the surface of the Gulf. This is compensated for by inflow from the Gulf of Oman, estimated at 500 meters/hour flow rate through the Strait of Hormuz.

\section{PREVIOUS RELATED WORK}

Work related to identification of suitable coastal areas for desalination in the region is vast. Following is a concise assessment of prior work related to this investigation.

Banat et al. [9] carried out a post-water coastal sea water pollution assessment of major nutrients, heavy metal ions, selected hydrocarbons, and selected bacterial community's counts at different sites along the coasts of the U.A.E. on the Arabian Gulf. The investigation found that Abu-Dhabi and Dubai coastal waters had occasional high nutrient levels with some fluctuations and wide spatial and temporal variations, suggesting the presence of anthropogenic sources of pollution creating these conditions near the sampling sites. Sharjah and Ajman Creeks had lower nutrient levels. The study revealed that slightly higher hydrocarbon concentrations were detected both in surface waters and sediments, attributed to deliberate release of crude oil into the Gulf waters during the Gulf War.

Malik et al. [10] provided results on the corrosion behavior of steels in Gulf seawater. The research presented some characteristics of the Gulf seawater consumption of various materials. The study stated the $\mathrm{pH}$ level of Gulf seawater to be 8.2 along with estimation of calcium, magnesium and sodium levels at 508, 1,618 and 13,440mg/l respectively.

Mohamed et al. [3] conducted a study to investigate the recirculation of salinity and temperature from the outfall of Mirfa power plant to the intake. Comparisons were drawn between simulated values and those collected in the field in terms of temperature and salinity at $2.0 \mathrm{~km}$ and $4.0 \mathrm{~km}$ from the coastline respectively. The study revealed that higher temperature and salinity occur close to the coast and decrease in the offshore direction. The work concluded that higher salinity and temperature close to the shoreline are due to the combined effect of the shallowness and the effluents from the plants.

Al-Lihaibi and Al-Omrani [11] measured petroleum hydrocarbons in offshore sediments from the central part of the Gulf. The analysis confirmed that concentrations varied between 4.0 and $56.2 \mu \mathrm{g} / \mathrm{g}$ wet sediment, with an average of $12.3 \mu \mathrm{g} / \mathrm{g}$. Highest concentrations were recorded in the north-west sector, with concentrations decreasing in a south-westerly direction. The study concluded that no significant correlations were observed between petroleum hydrocarbons and sedimentary organic carbon, mud content, sand content or gravel content and distributions of oil are considered to relate more closely to prevailing current and localized pollutant sources in the region.

Khan and Al-Ajmi [12] stated that "oil contamination of the Gulf is one of the most important environmental issues of the region and the Gulf is known as one of the most oiled areas of the 
world (GESAMP, 1993). The estimated oil pollution in the Gulf is about 3\% of the global total or nearly 50 times the average for a marine environment of its size as indicated by Golob and Bruss, [13]. Oil spillages are most common in the Gulf. According to an estimate by Hayes and Gundlach [14], nearly 21 million barrels $\left(3.3 \mathrm{Mm}^{3}\right)$ of oil were introduced in the northern section of the Gulf alone between 1977 and 1987. In addition, spills from well blow-outs such as the Nowruz oil well blow-out ( 2 million barrels) $\left(0.32 \mathrm{Mm}^{3}\right)$ in 1983 and spills such as the one during the 1990 Gulf War (6-8 million barrels) $\left(0.95-1.27 \mathrm{Mm}^{3}\right)$, have been some of the most massive in the world. Terrestrial sources and natural seepages substantially add to these inputs as revealed by Literathy [15]. As such, the oil pollution is ubiquitous in the Gulf. Beach oil and floating oil are frequently encountered and the oiling of critical habitats such as coral reefs has also occurred.

Within a coastal baseline study of pollutants in Bahrain, the U.A.E., and Oman, Fowler [16] observed that tar levels varied seasonally and loads on Omani beaches tended to be lower than the other coastal lines. The investigation demonstrated that the majority of tar originates from tankers de-ballasting and local oil spills. The ranges for tar values were $14-906 \mathrm{~g} / \mathrm{m}$ for Bahrain, $4-233 \mathrm{~g} / \mathrm{m}$ for the U.A.E., and $1-906 \mathrm{~g} / \mathrm{m}$ for Oman respectively.

From the above mentioned literature, work carried out on coastal water characteristics is extensive. (Reviewer 2 comment a) The objective of the present research is to carry out a comparison between Reverse Osmosis and Multi-Effect Distillation techniques, both incorporated within the existing district cooling plants of the U.A.E utilizing waste heat recovery Therefore the assessment is based on capital expenditure, operational costs and total power consumption, respectively. Current operational desalination and district cooling units are investigated and mathematical models are developed to determine economic feasibility of integration and evaluation of the two technologies respectively.

\section{DESALINATION CAPACITY IN THE U.A.E.}

The U.A.E. has a coastline of $1,318 \mathrm{~km}$ in length [8]. In addition, the U.A.E. has urbanized one of the most developed desalination system in the world which is mainly located along its shorelines. Currently there are 35 operational desalination plants in the region with the eight major ones are displayed in Figure 1. 


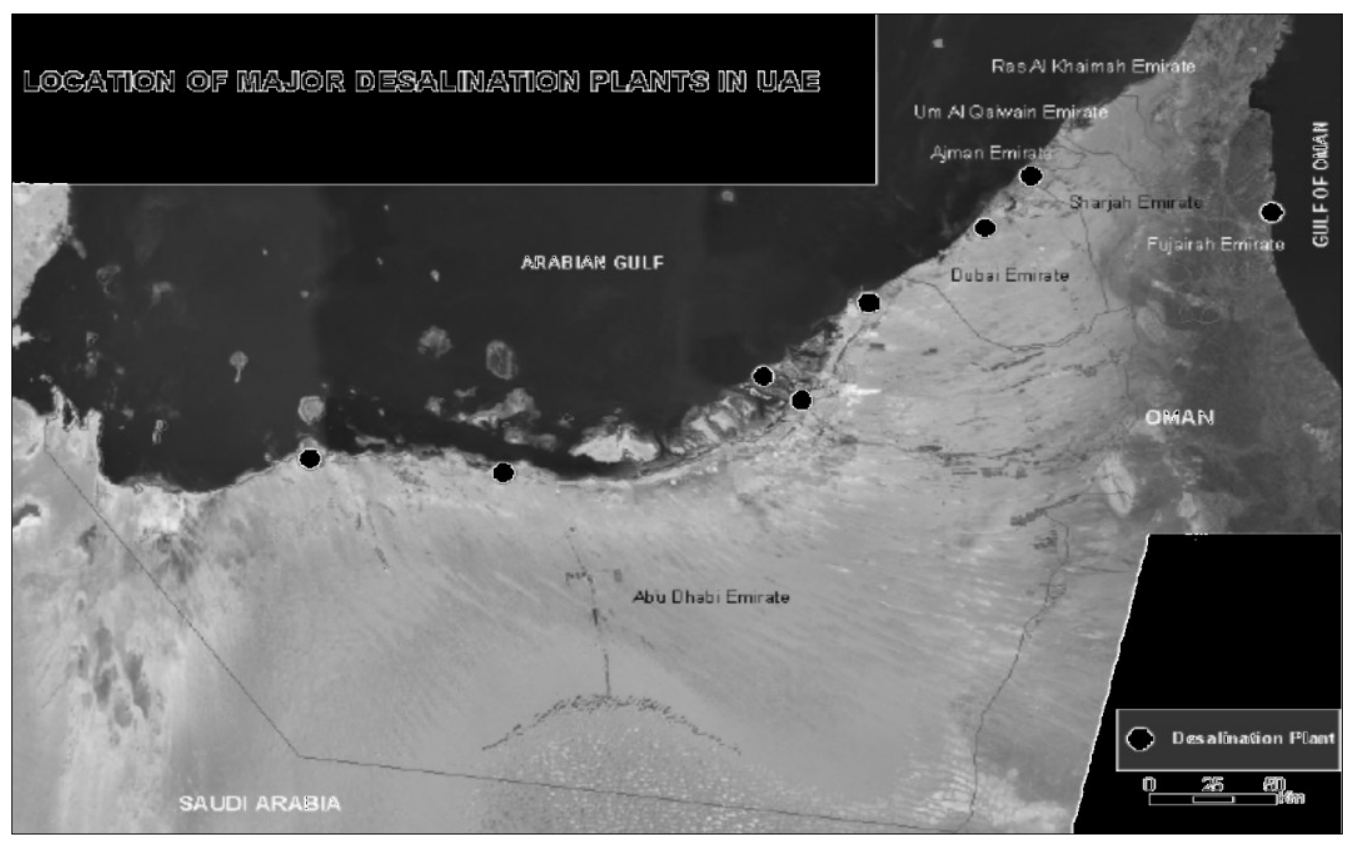

Fig.1 Location of the main desalination plants in the UAE [8].

The best desalination method to use on a water resource depends on the quantity and types of salts present. According to the World Health Organization [17], dissolved solids concentration, or salinity, of drinking water should be less than $500 \mathrm{mg} / \mathrm{l}$. it's estimated that less than $1 \%$ of the world's freshwater is easily accessible and has a salinity that is safe for human consumption.

Recent advances in distillation and membrane technology have dramatically improved performance and reliability, while reducing the cost of desalination. In fact, many arid countries now rely on seawater desalination as their primary source of fresh water. Constant enhancement in desalination economics are in occurrence at the same time as the expenditure of producing water from traditional sources increases. An increasing number of domestic and industrial water supply projects have taken into consideration desalination as an economically competitive, drought-proof water management opportunity, and in some cases the only selection. Figure 2 displays the gross capacity of water desalination in the region. 


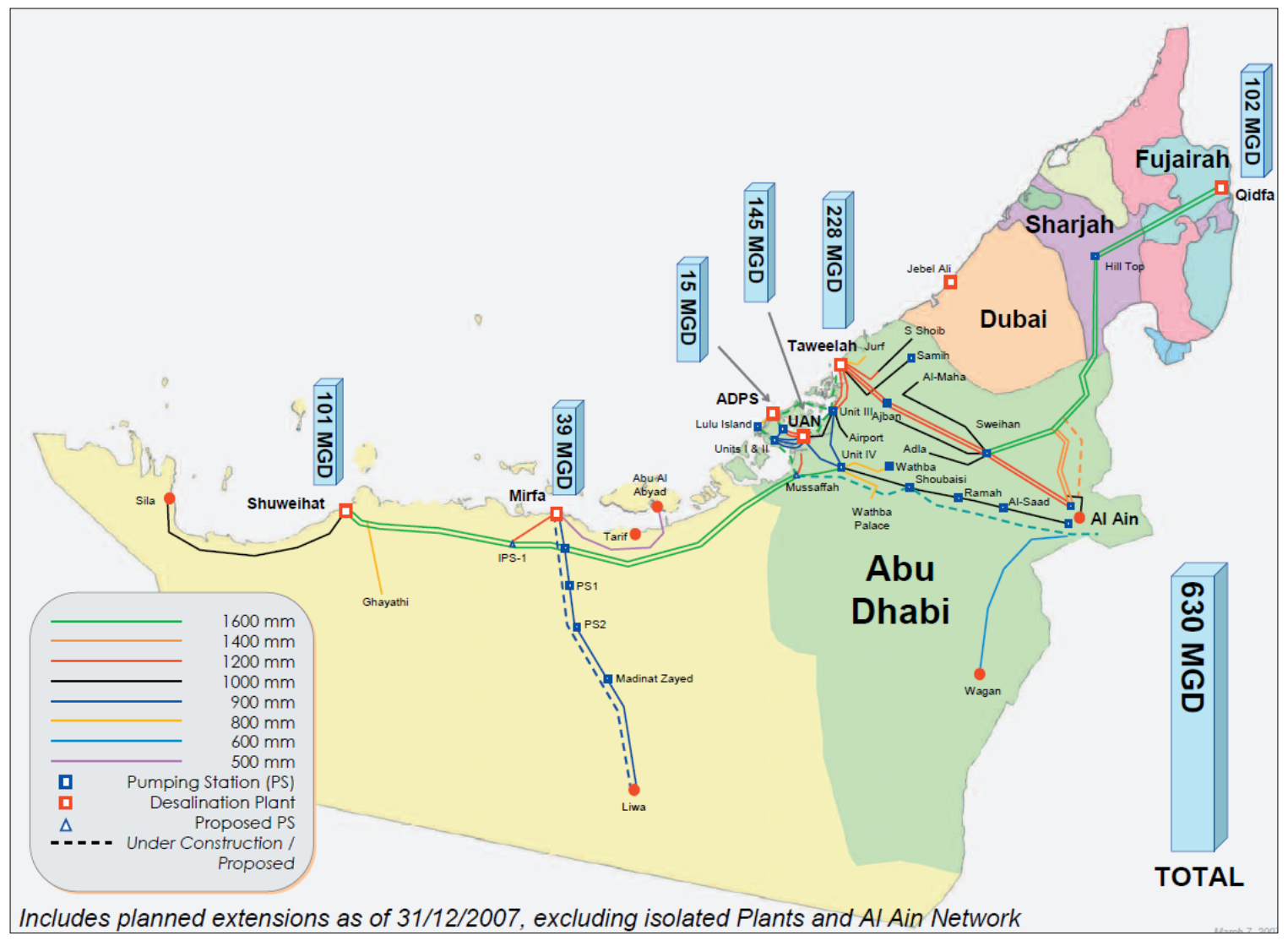

Fig. 2 Water Desalination Gross Capacity [18]

\subsection{Multiple Effect Distillation (MED)}

The MED process, also known as Multiple Effect Evaporation (MEE), is one of most common commercial methods of purifying seawater. In the MED process, distillation takes place in series of chambers, or effects, operating progressively lower pressure. The process takes advantage of the fact that water evaporates at successively lower temperature if the pressure decreases accordingly. Within each MED effect, cool seawater is sprayed over heat exchanger tube bundle (for shell and tube type evaporators) or falls on a plate surface (for plate type evaporators) while steam following on the other side of the heat exchanger surface, e.g. inside tube for shell and tube evaporators and on the other side of the plates in plate and frame heat exchangers. The thin seawater film evaporates as it absorbs heat from steam. The resulting vapor passes through mist eliminators to catch entrained brine droplets before the vapor is introduced as heating source to the next effect. The process is repeated through the length of the plant.

Modern systems have Gain Output Ratio (GORs) that range from 1.5 to 10 and operate at Top Brine Temperature (TBT) of $62^{\circ} \mathrm{C}$ to $75^{\circ} \mathrm{C}$ to minimize operational problems with scaling and corrosion that can occur at higher temperature. At these low TBTs, low-pressure steam can be used to drive the process. In some cases hot water at higher temperature can be used as well. Pumping power requirements usually ranges from 0.7 to $1.2 \mathrm{kWh}$ per cubic meter of distillate 
produces. Operating at these relatively low temperatures requires handling large volume of vacuum vapor. As the MED unit size increases, achieving efficient vapor movement becomes further imperative. Oxygen, carbon dioxide, and other gases dissolved in seawater are released during the evaporation process. The vacuum is which the system operates may also draw air into the effects through small leaks in the vessel walls. If these Non-Condensable Gases (NCGs) are allowed to accumulate within the system, they may hinder heat transfer by a process known as gas blanketing. A venting system must be incorporated within the system to ensure the NCGs are continuously swept away from the heat transfer surfaces. The venting system typically use a combination of steam jet ejector or vacuum pump accessorized with small condenser to completely evacuate the NCGs to the atmosphere.

\subsection{Operational desalination plants in the U.A.E.}

Water sources in U.A.E. include ground, surface, desalinated and treated wastewater respectively. Various water treatment technologies are utilized extensively for desalination including the multi stage flashing, multiple effect distillation and reverse osmosis. There are four major government entities involved in the field which include Abu Dhabi Water \& Electricity Authority (ADWEA) [19], Dubai Electricity \& Water Authority (DEWA) [20], Sharjah Electricity \& Water Authority (SEWA) [21] and Federal Electricity \& Water Authority (FEWA) [22] from which the respective data was obtained and accumulated. Tables 1 and 2 display the summarized operational current and future desalination plants by listed suppliers in the U.A.E having a capacity of in excess of $100,000 \mathrm{~m}^{3} /$ day.

Table 1 Summary of the total capacity by suppliers of current desalination projects in the UAE $[19,20,21,22,23]$

\begin{tabular}{|l|l|}
\hline Desalination Supplier & Capacity $\left(\mathbf{m}^{\mathbf{3}} / \mathbf{d}\right)$ \\
\hline Abu Dhabi Water \& Electricity Authority (ADWEA) & $4,045,000$ \\
\hline Dubai Electricity \& Water Authority (DEWA) & 850,000 \\
\hline Sharjah Electricity \& Water Authority (SEWA) & 288,670 \\
\hline Grand Total & $5,183,670$ \\
\hline
\end{tabular}

Table 2 Summary of the total capacity by suppliers of future desalination projects in the UAE [19,20,21,22,23]

\begin{tabular}{|l|l|}
\hline Desalination Supplier & Capacity $\left(\mathbf{m}^{\mathbf{3}} / \mathbf{d}\right)$ \\
\hline Abu Dhabi Water \& Electricity Authority (ADWEA) & $1,546,000$ \\
\hline Dubai Electricity \& Water Authority (DEWA) & $1,065,000$ \\
\hline Federal Electricity \& Water Authority (FEWA) & 545,700 \\
\hline Grand Total & $3,156,700$ \\
\hline
\end{tabular}


Figure 3 displays the graphical representation the total design capacity of the operational desalination units in terms of percentage distribution over the major cities of the U.A.E. As displayed, Dubai accounts for approximately $53.2 \%$ of the country's desalinated water production along with Abu Dhabi, which supplies an estimated percentage of desalination projects in excess of $35 \%$. The largest desalination in the region by design capacity is the Fujairah F2 IWPP $\left(590,000 \mathrm{~m}^{3} /\right.$ day) located in the Fujairah as a part of Abu Dhabi Water and Electricity Authority.

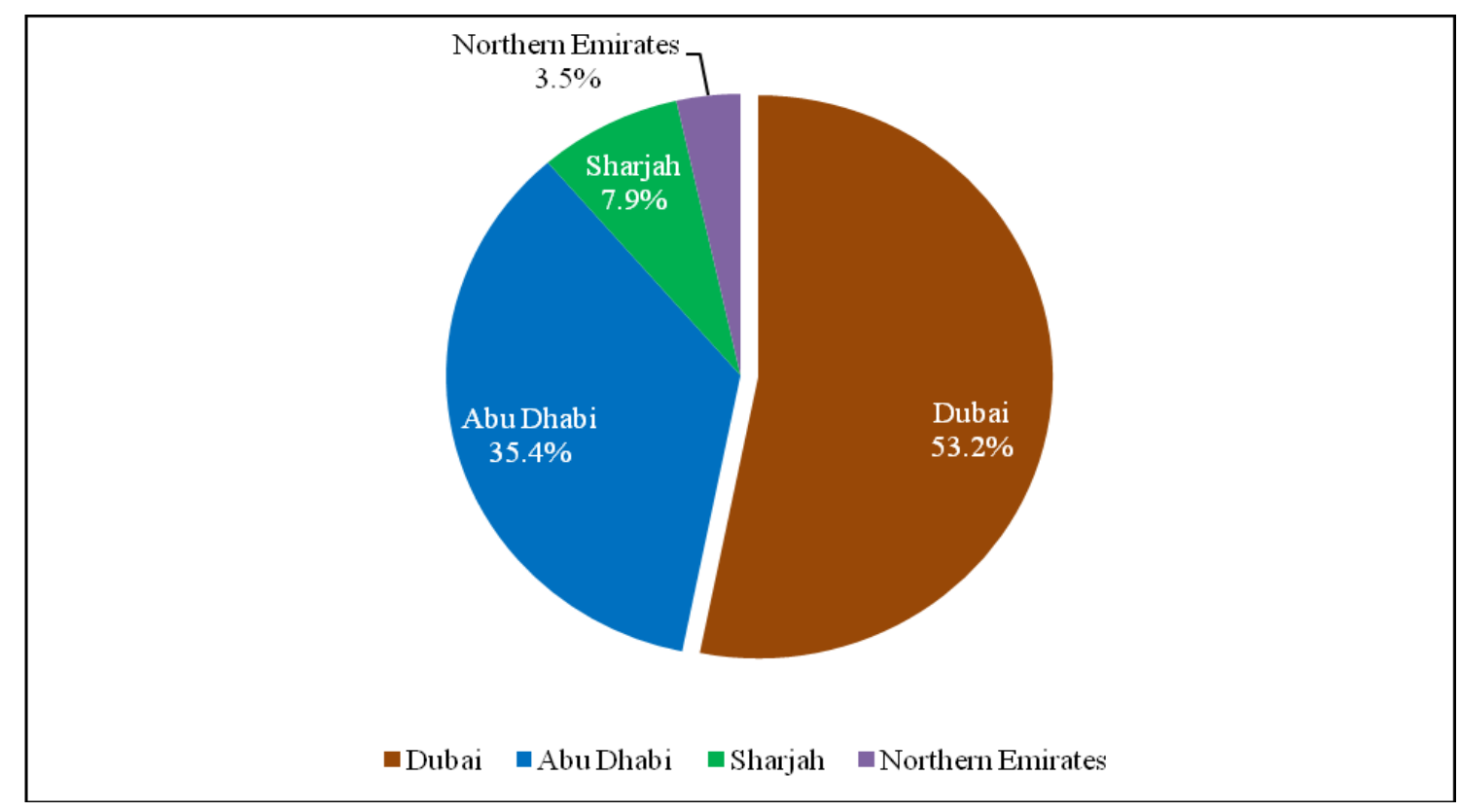

Fig.3 Percentage distribution of the total desalination capacity across the U.A.E.

\section{DISTRICT COOLING CAPACITY IN THE U.A.E.}

District cooling refers to the means of producing distributed and centralized cooling energy. The process includes chilled water delivery via an underground insulated pipeline to workplace, manufacturing and suburban buildings for the purpose of providing cold air within a district. Specifically designed equipment for each individual structure then utilize this cold water to lower the air temperature passing through the building's air conditioning system. There are currently two types of district cooling facilities in the U.A.E., which can be categorized into large and small scale plants with the latter being used mainly in the resort and hotel chains for their individual amenities and cliental. Table 3 highlights the large scale district cooling facilities in the U.A.E over a capacity of $100,000 \mathrm{~m}^{3} /$ day. 
Table 3 Major district cooling plants in the U.A.E. over a capacity of $100,000 \mathrm{~m}^{3} /$ day $[24,25,26,27,28,29]$

\begin{tabular}{|l|l|l|l|}
\hline District Cooling Suppliers & District Cooling Projects & City & Capacity (TR) \\
\hline Emirates District Cooling L.L.C. (EMICOOL) & Motor City Project & Dubai & 100,000 \\
\hline Emirates District Cooling L.L.C. (EMICOOL) & Dubai Investments Park & Dubai & 125,000 \\
\hline Emirates Central Cooling Systems Corporation (EMPOWER) & The Lagoons & Dubai & 300,000 \\
\hline Emirates Central Cooling Systems Corporation (EMPOWER) & Dubailand Residential Complex & Dubai & 160,000 \\
\hline Emirates Central Cooling Systems Corporation (EMPOWER) & Knowledge Village (Academic City) & Dubai & 110,000 \\
\hline Emirates Central Cooling Systems Corporation (EMPOWER) & City of Arabia & Dubai & 120,000 \\
\hline Emirates Central Cooling Systems Corporation (EMPOWER) & International Media Production Zone & Dubai & 140,000 \\
\hline Emirates Central Cooling Systems Corporation (EMPOWER) & Dubai World Trade Centre & Dubai & 168,000 \\
\hline National Central Cooling Company (TABREED) & Yas Island & Abu Dhabi & 600,000 \\
\hline National Central Cooling Company (TABREED) & Al Raha Beach Development & Abu Dhabi & 400,000 \\
\hline National Central Cooling Company (TABREED) & Dubai Metro & Dubai & 300,000 \\
\hline City Cool L.L.C. & Sharjah Investment Centre & Sharjah & 115,000 \\
\hline
\end{tabular}

Figure 4 displays a graphical illustration in terms of cooling capacity in Tons of Refrigeration (TR) of the existing district cooling schemes in the region.

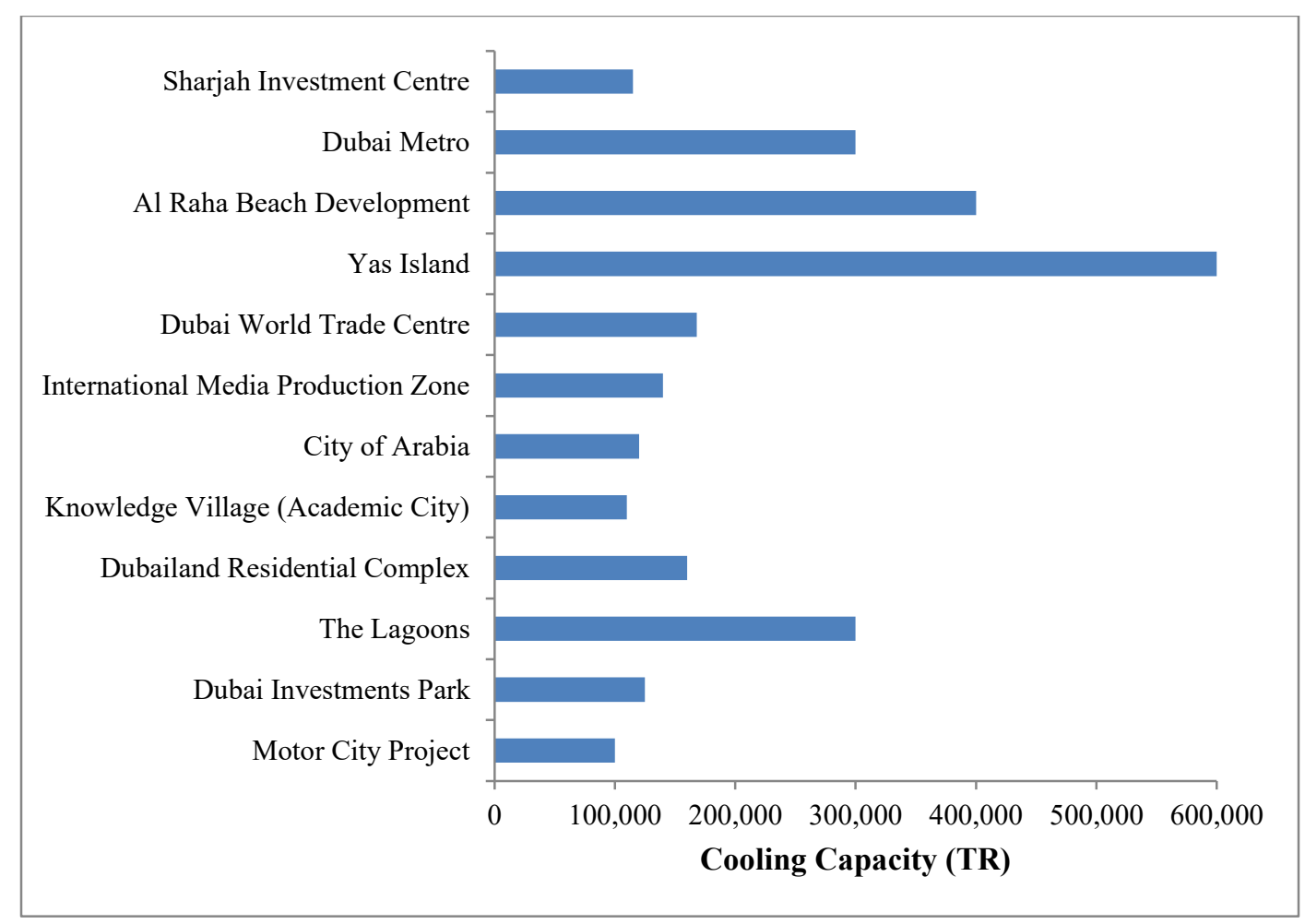

Fig. 4 Capacity representation of the district cooling projects across the U.A.E. over a capacity of $100,000 \mathrm{~m}^{3} /$ day 
As observed in Figure 4, it is evident that there lies a large capacity of district cooling technology currently in the country, with major projects located in Dubai and Abu Dhabi due to it being the most developed and populated areas of the country.

\section{COMBINED DESALINATION AND DISTRICT COOLING}

Currently there are no combined reverse osmosis and district cooling systems in operation, there are however multi-effect distillation/desalination systems. This section describes the waste heat recover used to combine the systems and thus by replacing the MED with RO in the analysis we establish the viability of such a system as a direct comparison in the results section of this work.

\subsection{Waste heat recovery}

One of the foremost advantages of installing the MED technology is its suitability to adapt to any heat resource including waste heat from industrial power generation processes. The combined [30] operation of using waste heat from buildings to power the MED desalination scheme is an advanced coupling approach to make use of the waste heat therefore resulting in much lower costs of operation and the overall carbon footprint.

Figure 5 displays the schematic representation of heat and mass balance design for MED process unit integrated with an external thermal source produced from waste heat in buildings to identify the suitability for coupling district cooling with desalination technology.

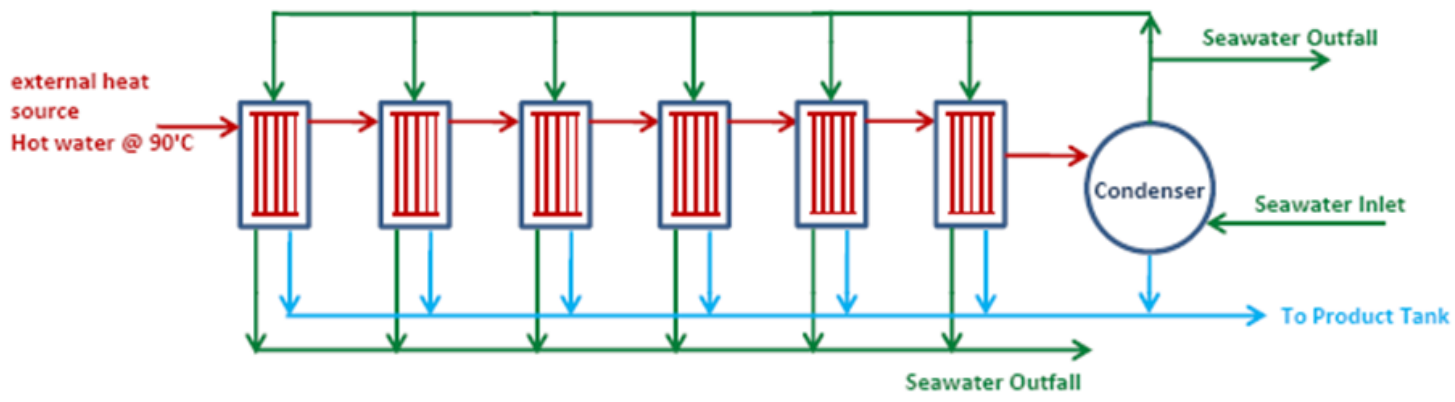

Fig.5 Schematic of the heat and mass balance design of the MED unit

The characteristic of this unit are six plate type evaporators/condensers as effects and one final condenser and their accessories. There is no flash chamber for collecting brine to be flashed and it is assumed that distillate from each effect are collected without heat recovery process and then sent to the storage tank.

The intake temperature and feed values along with the vapor generated are summarized for individual effect in table 4 . 
Table 4 Summary of heat and flow estimation for individual effect

\begin{tabular}{|llll|}
\hline In Summary & Temperature $\left({ }^{\circ} \mathbf{C}\right)$ & Feed $\left(\mathbf{m}^{\mathbf{3}} / \mathbf{h r}\right)$ & Vapor Generated $\left(\mathbf{m}^{\mathbf{3}} / \mathbf{h r}\right)$ \\
\hline Effect \# 1 & 65.00 & 23.40 & 7.12 \\
Effect \# 2 & 61.00 & 23.40 & 6.74 \\
Effect \# 3 & 57.00 & 19.80 & 5.65 \\
Effect \# 4 & 53.00 & 19.80 & 5.33 \\
Effect \# 5 & 49.00 & 16.20 & 4.52 \\
Effect \# 6 & 45.00 & 16.20 & 4.45 \\
& Total & 118.80 & 33.82 \\
& & \\
\hline & & \\
Hot water inlet at $90^{\circ} \mathrm{C}\left(\mathrm{m}^{3} / \mathrm{hr}\right)$ & 215.00 & \\
Seawater inlet at $33^{\circ} \mathrm{C}\left(\mathrm{m}^{3} / \mathrm{hr}\right)$ & 318.70 & \\
Total produced fresh water $\left(\mathrm{m}^{3} /\right.$ day $)$ & 812.00 & \\
GOR & 4.94 \\
\hline
\end{tabular}

The heat source for this MED plant is considered $90^{\circ} \mathrm{C}$ hot water with total energy of $5 \mathrm{MW}$. Further computation revealed that the distillation unit GOR had a value of approximately 5 (4.95), along with 812 $\mathrm{m} 3$ /day net production of fresh water supply.

\section{RESULTS AND DISCUSSION}

\subsection{Power consumption analysis}

A numerical model was established in order to estimate and compare the power consumption requirements of combining a Reverse-Osmosis (RO) plant and MED technology with district cooling respectively. The data draws assumptions that the district cooling technologies are of similar power consumption due to type and date of commissioning, thus allows a comparison of technologies. Table 5 displays the power consumption figures respectively.

Table 5 Power consumption data per individual technology

\begin{tabular}{|ll|}
\hline Technology & Power Consumption (MW) \\
\hline Reverse Osmosis & 4.00 \\
District Cooling & 1.65 \\
Combined RO-DC & $\mathbf{5 . 6 5}$ \\
Multiple Effect Distillation & 5.00 \\
District Cooling & 1.65 \\
Combined MED-DC & $\mathbf{6 . 6 5}$ \\
\hline
\end{tabular}

Figure 6 shows the integrated power consumption evaluation between MED and RO technologies in combination with district cooling. As observed, the MED integrated district cooling has a higher estimated consumption of electrical power at $54.1 \%$ in comparison to RO 
which estimates at $45.9 \%$ depicting an increase of $8.20 \%$ between the two technologies respectively.

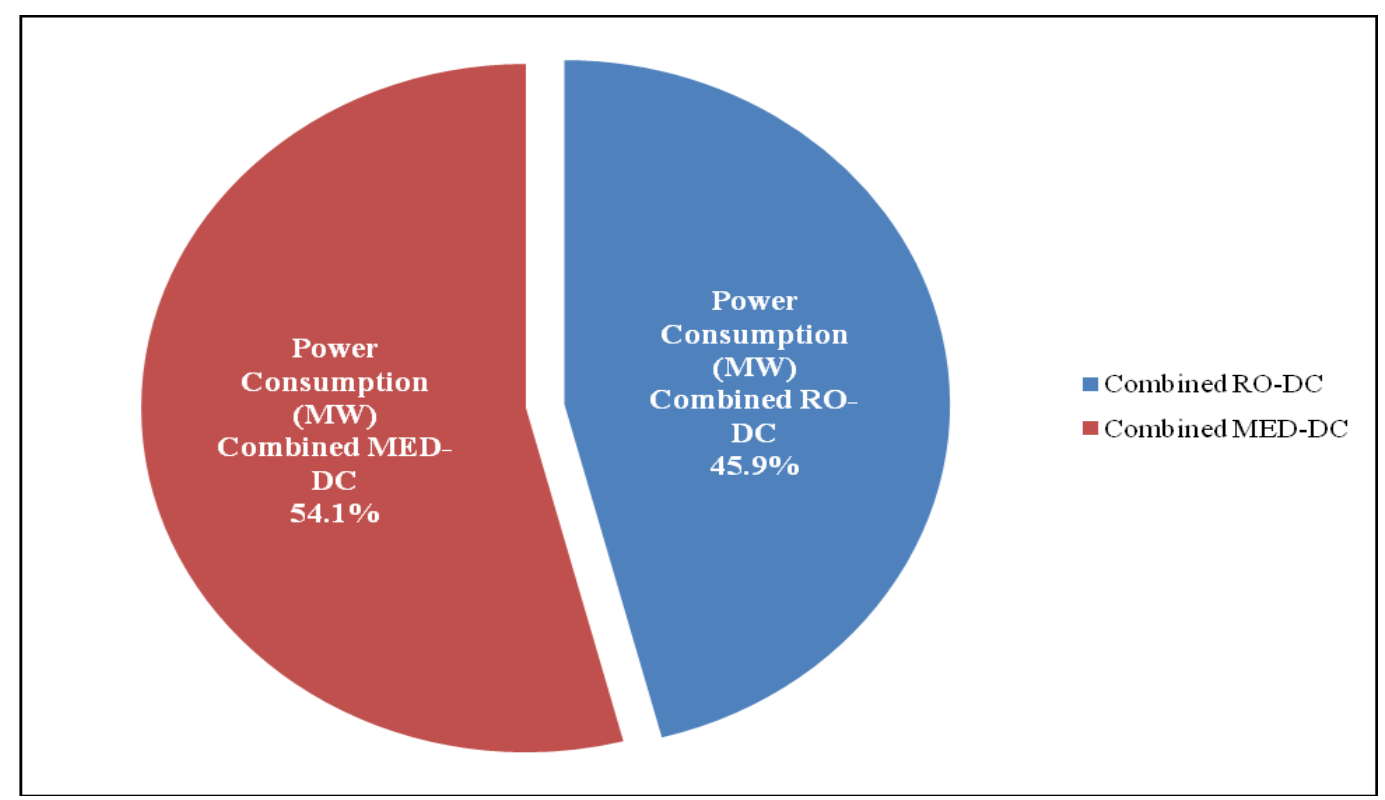

Fig.6 Proportion of power consumption per individual technology

From the investigated data it is apparent that while the RO system is energy intensive mainly due to the high pressure pumping requirements, the MED system consumes a higher percentage of energy due to the complicated coupling of power stations with desalination units especially in urban or semi-urban which are away from the sea district.

\subsection{Cost analysis}

Table 6 summarizes the initial capital expenditure of the individual and combined technologies.

Table 6 Capital expenditure per individual technology

\begin{tabular}{|ll|}
\hline Technology & Capital Expenditure (\$) \\
\hline Reverse Osmosis & $1,200,000$ \\
District Cooling & $2,145,000$ \\
Combined RO-DC & $\mathbf{3 , 3 4 5 , 0 0 0}$ \\
Multiple Effect Distillation & $1,846,154$ \\
District Cooling & $2,145,000$ \\
Combined MED-DC & $\mathbf{3 , 9 9 1 , 1 5 4}$ \\
\hline
\end{tabular}

Capital cost for a typical RO plant is almost $65 \%$ of the MED plant with district cooling costs being identical for both desalination techniques. District cooling makes up in excess of 53\% of the overall cost of the integrated MED system and in excess of $64 \%$ of the integrated RO system. 
As observed, the MED integrated district cooling has a higher estimated proportion of capital expenditure at $54.4 \%$ in comparison to RO which estimates at $45.6 \%$ depicting an increase of $8.80 \%$ between the two technologies respectively as illustrated in Figure 7.

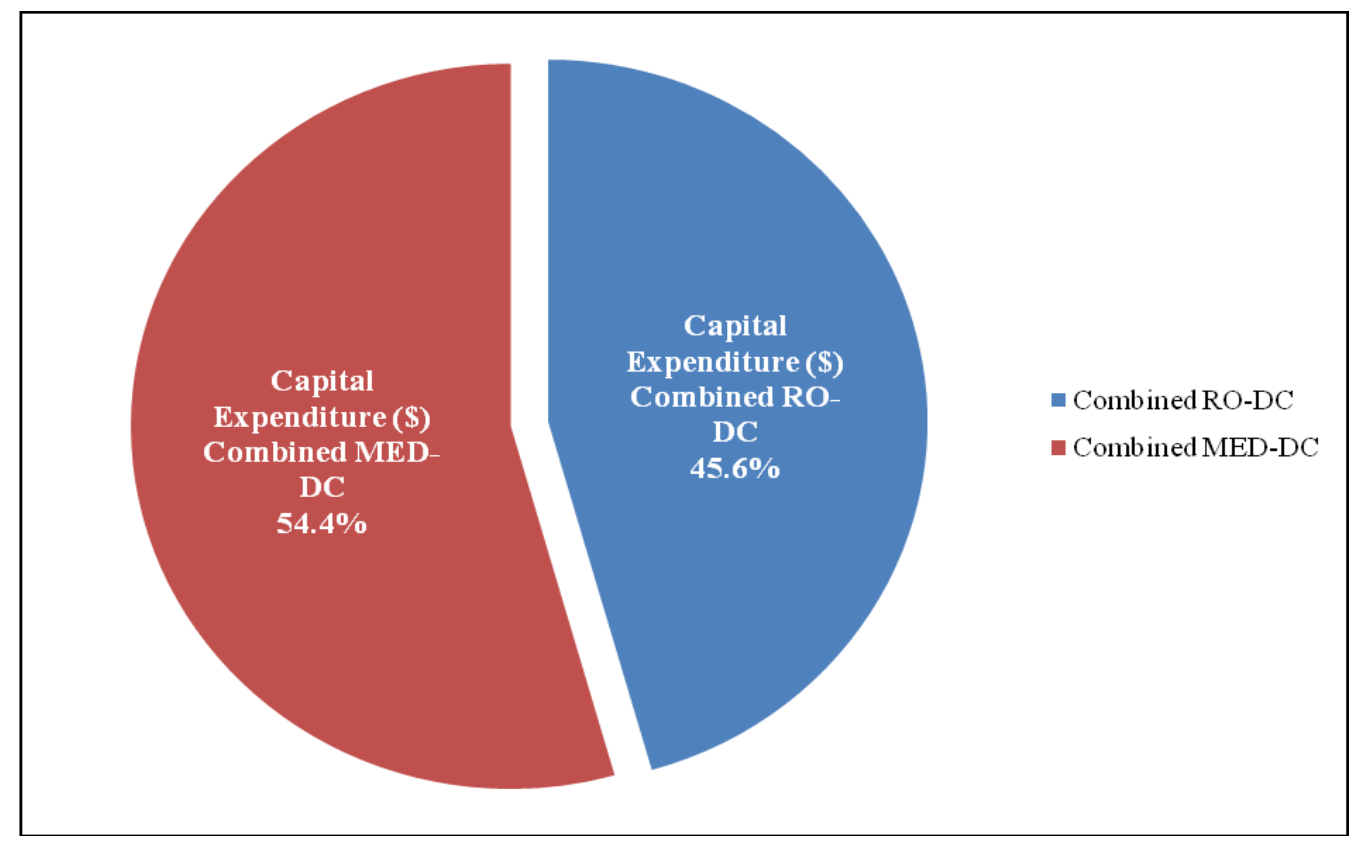

Fig.7 Proportion of capital expenditure per individual technology

Having analyzed the power consumption and initial capital expenditure of the individual and coupled desalination technologies with district cooling along with the potential of waste heat recovery aspect for the MED related design, graphical results were established for the total operational costs over the typical system lifetime. Current tariff for industrial consumption from DEWA was considered at a value of $\$ 0.06$ per $\mathrm{kWh}$. Table 7 displays the total operational expenditure per individual and combined desalination and district cooling scheme.

Table 7 Total operational costs per individual technology

\begin{tabular}{|ll|}
\hline Technology & Annual Operational Cost (\$) \\
\hline Reverse Osmosis & 89,352 \\
District Cooling & 133,502 \\
Combined RO-DC & $\mathbf{2 2 2 , 8 5 4}$ \\
Multiple Effect Distillation & 0 \\
District Cooling & 133,502 \\
Combined MED-DC & $\mathbf{1 3 3 , 5 0 2}$ \\
\hline
\end{tabular}

With reference to Figure 8, the total cost of operation for combined desalination and district cooling is drawn involving waste heat recovery system. As observed, the total cost of MED integrated with district cooling is approximately $25 \%$ lower than the RO combined system. 


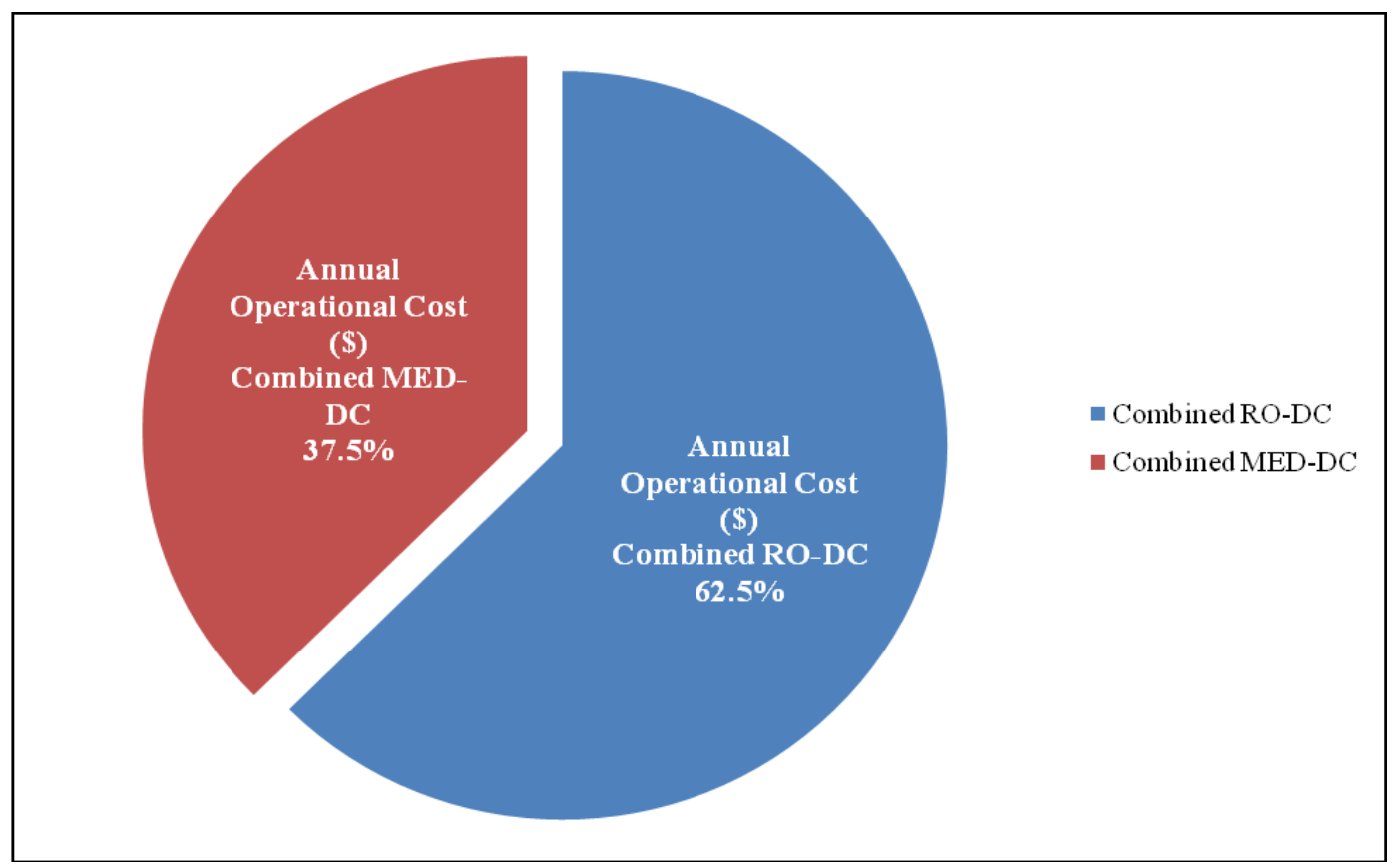

Fig.8 Proportion of operational costs per individual technology

By utilizing the thermal waste from buildings, the cost of external power input from the MED plant is dropped to zero, (Electrical power is required for the seawater, chemical dosing, brined discharge and distillate collection pumping, however these are not significant), thus balancing against the higher capital expenditure and therefore reducing the overall operation expenditure.

Figure 9 displays the cumulative capital and operational costs of the combined MED and RO desalination technologies with district cooling over a 15 year characteristic system lifetime.

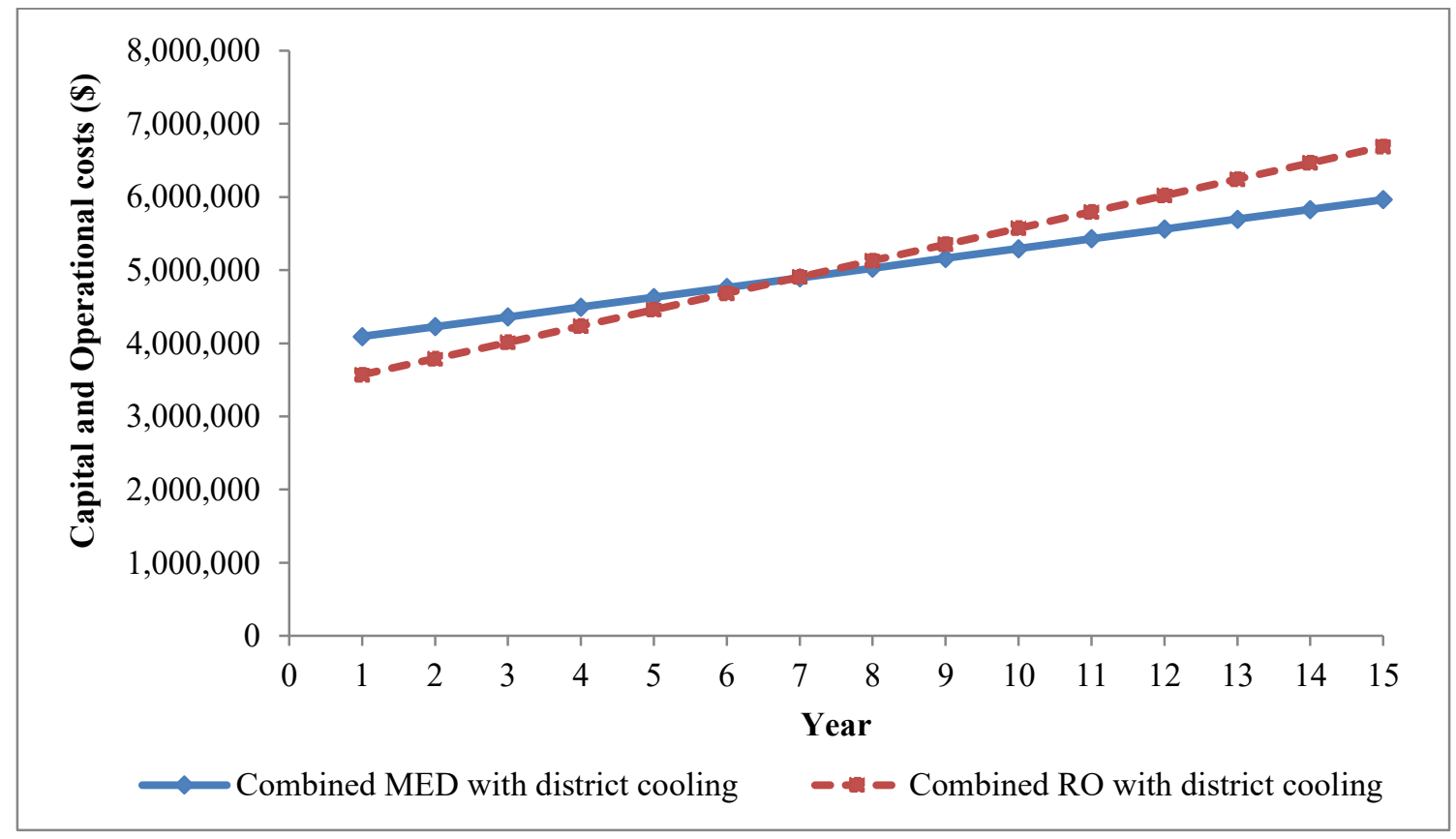


Fig.9 Cumulative costs variation across the system life-cycle

As expected, both lines signify a linear variation and an increasing gradient with respect to time. It is observed that the MED coupled district cooling system breaks even against the RO coupled district cooling at approximately 6.5 years, and continues to be more cost effective for the remainder of the life-cycle. Considering a typical 15 year life-cycle, the MED coupled district cooling system shows further cost efficiency on average for the majority of the plant life thus highlighting the reduction in overall energy consumption and enhancing the overall efficiency of the solution.

\subsection{Long term economic viability}

Energy prices are escalating globally and thus the price of electricity is set to increase. Currently the price of electricity in the UAE is subsidized by the government, the definitive amount of subsidy is not published. However with the rate of development across the UAE coupled with dwindling oil reserves it seem likely that this subsidy is not sustainable for the 15 year life cycle of the proposed plant analysed here.

A comparison between the highest $(\$ 0.10$ per $\mathrm{kWh})$ and lowest $(\$ 0.06$ per $\mathrm{kWh})$ [20] Industrial electricity consumption tariff (Figure 10) was performed to determine the impact on the total costs of the two studied technologies (combined MED with district cooling and combined RO with district cooling) respectively.

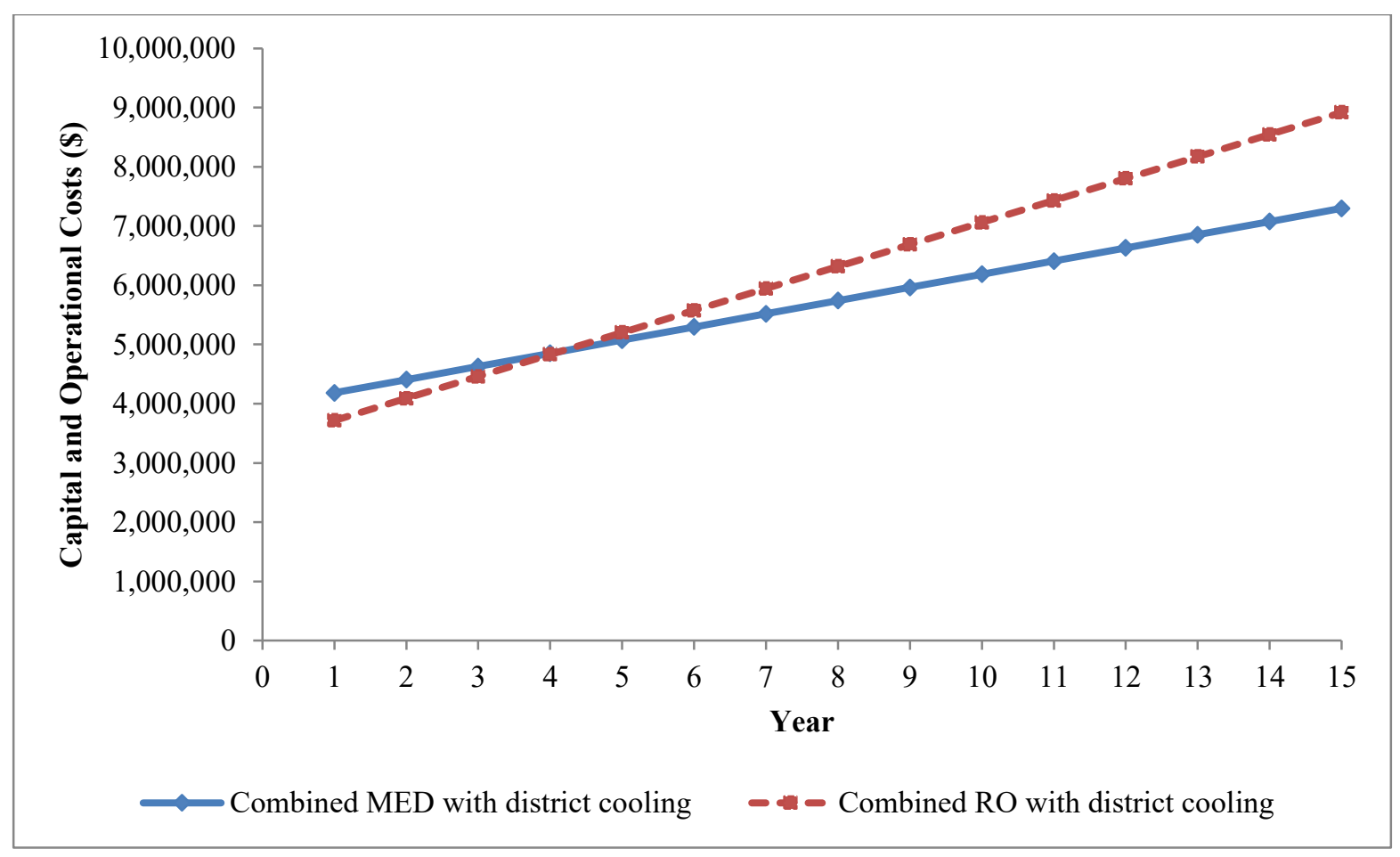

Fig10 Cumulative costs variation across the system life-cycle $(\$ 0.10$ per $\mathrm{kWh})$ 
From the studied data, it is displayed that the MED coupled district cooling system breaks even against the RO coupled district cooling at 4 years, and continues to be more cost effective for the remainder of the life-cycle.

\section{CONCLUSION}

The investigation demonstrated the feasibility of utilizing waste heat for combined technology of MED and district cooling is more cost effective than using the technologies independently. Further comparisons were drawn between MED and RO integrated district cooling systems and it was revealed that the former consumes an estimated $25 \%$ a lesser amount of operational costs than the latter.

In addition, the current RO plants in the U.A.E. produce at operational costs of $\$ 0.30 / \mathrm{m}^{3}$ which is in agreement with the recent studies conducted by Akgul et al. [31] which stated operational costs of $\$ 0.21 / \mathrm{m}^{3}$ for the latest RO technologies in Turkey. Comparatively, the RO desalination process consumes approximately a third of the total system consumption, thus the operational cost of MED technology is $\$ 0.15 / \mathrm{m}^{3}$, therefore making the system competitive in terms on innovation and available technology. Furthermore with energy prices set to increase over the next decade the combined MED/District cooling system becomes the most economically viable solution for the UAE.

\section{ACKNOWLEDGMENTS}

The authors would like to acknowledge the technical support and information from Star Refrigeration and in particular the NeatDesal team in carrying out this investigation. 


\section{REFERENCES}

1. R. Michael Reynolds, Physical oceanography of the Gulf, Strait of Hormuz, and the Gulf of OmanResults from the Mt. Micthell Expedition, Marine Pollution Bulletin, vol. 27, (1993), pp. 35-59.

2. P.G. Brewer and D. Dryssen, Chemical oceanography of the Persian Gulf. Progress in Oceanography, 14 (1985) 41-55

3. Khaled A. Mohamed, Ahmed Arieqat, Mufeed Odeh, Set-up of a mid-field model to investigate the recirculation of effluents in the Mirfa power and desalination plant desalination 166 (2004) 401-409

4. K. Banse, Irregular flow of Persian (Arabian) Gulf water to the Arabian Sea, J. Mar. Res. 55 (1997) 10491067.

5. J.R. Hunter, A review of the residual circulation and mixing processes in the Kuwait Action Plan (KAP) region, with reference to applicable modeling techniques, Oceanography Modeling of the KAP region

6. Faiza Al Yamani, J.M. Bishop and G.R. Morgan, Assessment of the effects of the Shatt El-Arab's altered discharge regimes on the ecology of the Northern Arabian Gulf, final report, KISR Project FM006K, Kuwait Institute for Scientific Research, (July 1995).

7. Andrew R. G. Price and Stephen L. Coles, Aspects of seagrass ecology along the western Arabian Gulf coast, Hydrobiologia 234 : 129-141, 1992

8. Mike Brook and Mohamed A. Dawoud, Coastal water resources management in the United Arab Emirates, Environmental Research and Wildlife Development Agency, Integrated coastal zone management in the United Arab Emirates, 5-8 June 2005, Abu Dhabi United Arab Emirates

9. I.M. Banat, E.S. Hassan, M.S. EI-Shahawi, and A.H. Abu-Hilal, Post-Gulf-War assessment of nutrients, heavy metal ions, hydrocarbons, and bacterial pollution levels in the United Arab Emirates coastal waters, Environment International Vol. 24, No. 1/2, pp. 109-116, 1998

10. Anees U. Malik, Shahreer Ahmad, IsmaeelAndijani, Saleh Al-Fouzan, Corrosion behavior of steels in Gulf seawater environment, WSTA 4th Gulf Conference, Bahrain, 13-18 February 1999, also in Desalination Vol. 123, 1999, p. 205-213.

11. Sultan S. Al-Lihaibi and Laila Al-Omrani, Petroleum Hydrocarbons in Offshore Sediments from the Gulf, Marine Pollution Bulletin, Vol. 32, No. 1, pp. 65-69, 1996.

12. NuzratYar Khan and Dhari Al-Ajmi, Post-War Imperatives for the Sustainable Management of the Gulf Ecosystem, Environment International, Vol. 24, No. 1/2, pp. 239-248, 1998.

13. Golob, R.; Bruss, E. Statistical analysis of oil pollution in the Kuwait Action Plan Region and the implications of selected world-wide oil spills to the region combating oil pollution in the Kuwait Action Plan Region. IMO/ROPMEAJNEP. UNEP Regional Seas Reports and Studies No. 44. New York, NY: United Nations Environment Program; 1984.

14. Hayes, M.O.; Gundlach, E.R. Oil pollution in the Arabian Gulf. A preliminary survey Report 70GOP; 1987. Available from: Research Planning Institute, Columbia, SC

15. Literathy, P. Considerations for the assessment of environmental consequences of the 1991 Gulf War. Mar. Pollut. Bull. 27: 349- 356; 1993.

16. Fowler, S. W. Coastal baseline studies of pollutants in Bahrain, UAE and Oman. ROPME symposium on regional marine monitoring and research programs. Al-Ain, UAE: UAE University; 1985.

17. World Health Organization [Online], 2011, available from http://www.who.int/en/ (access date 27 February 2011)

18. Abu Dhabi water and electricity company (ADWEA) statistical report 1998-2006, [Online], 2011 available from http://www.adwec.ae/documents/report/2006/water/water_charts2006.pdf (access date 27 February 2011)

19. Abu Dhabi Water \& Electricity Authority [Online], 2011, available from http://www.adwea.ae/eng/index.html (access date 27 February 2011)

20. Dubai Electricity \& Water Authority [Online], 2011, available from http://www.dewa.gov.ae/english/default.aspx (access date 27 February 2011)

21. Sharjah Electricity \& Water Authority [Online], 2011, available from http://www.sewa.gov.ae/English/ (access date 27 February 2011)

22. Federal Electricity \& Water Authority [Online], 2011, available from http://www.fewa.gov.ae/index_en.html (access date 27 February 2011)

23. Global Water Intelligence (GWI), Annual Report 2008, 2009 and 2010 
24. AMEinfo [Online], 2011, available from http://www.ameinfo.com/109893.html (access date 27 February 2011)

25. Empower - Energy Solutions [Online], 2011, available from http://www.empower.ae (access date 27 February 2011)

26. Tabreed schemes[Online], 2011, available from http://www.tabreed.co.ae/ (access date 27 February 2011)

27. City Cool L.L.C. [Online], 2011, available from http://www.city-cool.com (access date 27 February 2011)

28. Drake \& Scull ongoing projects [Online], 2011, available from http://www.drakescull.com/en/ProjectsOngoing.aspx (access date 27 February 2011)

29. Cimac Quality Integrated Solutions [Online], 2011, available from http://www.cimac.ae/districtcooling.html (access date 27 February 2011)

30. Star Refrigeration - Total Solutions Provided [Online], 2011, available from http://www.starref.co.uk/star/neatdesal.htmlml (access date 27 February 2011)

31. Akgul, D. Cakmakci, M. Kayaalp, N. and Koyuncu, I. (2008). Cost Analysis of Seawater Desalination with Reverse Osmosis in Turkey. Desalination 220, pg 123-131, Elsevier. 